\title{
RT-PCR for Confirmation of Echovirus 30 Isolated in Belém, Brazil
}

\author{
Maria de Lourdes C. Gomes ${ }^{1}$, Lauze Lee A. Ferreira ${ }^{2}$, Rodrigo Henryque Gomes ${ }^{2}$, Letícia M. Lamarão ${ }^{3}$, Edna da Silveira ${ }^{1}$, Lílian \\ da Silva Rodrigues ${ }^{4}$, Cláudio Ferreira da Silva $^{4}$ and Eduardo Ribeiro de Almeida ${ }^{4}$ \\ ${ }^{I}$ Virology Section, Evandro Chagas Institute; Ananindeua, PA; ${ }^{2}$ Federal University of Pará; Belém, PA; ${ }^{3}$ Federal University of Bahia; Salvador \\ BA; ${ }^{4}$ Health Unit of District of Pedreira; Belém PA, Brazil
}

Echovirus (Echo) 30 or human enterovirus B is the most frequent enterovirus associated with meningitis cases. Epidemics and outbreaks of this disease caused by Echo 30 have occurred in several countries. In Brazil, Echo 30 has been isolated from sporadic cases and outbreaks that occurred mainly in the south and southeast regions. We used RT-PCR to examine Echo 30 isolates from meningitis cases detected from March 2002 to December 2003 in Belém, state of Pará, in northern Brazil. The patients were attended in a Basic Health Unit (State Health Secretary of Pará), where cerebrospinal fluid (CSF) was collected and stored in liquid nitrogen. Weekly visits were made by technicians from Evandro Chagas Institute to the health unit and samples were stored at $-\mathbf{7 0}^{\circ} \mathrm{C}$ in the laboratory until use. HEp-2 and RD cell lines were used for viral isolation and neutralization with specific antisera for viral identification. RNA extraction was made using Trizol reagent. The RT-PCR was made in one step, and the total mixture $(50 \mu \mathrm{L})$ was composed of: RNA, reaction buffer, dNTP, primers, Rnase inhibitor, reverse transcriptase, Taq polymerase and water. The products were visualized in agarose gel stained with ethidium bromide, visualized under UV light. Among the 279 CSF samples examined, 30 (10.7\%) were EV positive, 29 being Echo 30 and one was Cox B. Nineteen Echo 30 were examined with RT-PCR; 18 tested positive (762 and 494 base pairs). The use of this technique permitted viral identification in less time than usual, which benefits the patient and is of importance for publichealth interventions.

Key-Words: Echovirus 30, aseptic meningitis, RT-PCR, Belém, Brazil.

Echovirus (Echo) 30 is a member of the Enterovirus genus in the Picornaviridae family, which is subdivided into five species: Human Poliovirus and Human Enterovirus (HEV) types A, B, C and D, each one with several serotypes. This genus was originally divided into: Poliovirus, Coxsackievirus (Cox) A and B, Echovirus (Echo) and Enterovirus (EV). Almost all Echo belong to the species HEV B; they are more frequently associated with aseptic meningitis (AM). Epidemics and/or outbreaks of this disease have occurred in Panama, Mexico, Romania, Switzerland, Cuba, United States of America and Turkey. In Panama, it was identified as Echo 4, in Mexico, Romania and Switzerland as Echo 30, and in Cuba, USA and Turkey as Echo 16, 13 and 30, respectively [1-7]. In Brazil during the 1960s, Godoy et al. [8] reported cases of AM associated with enteroviruses. Later studies have confirmed this association [9-13], including two outbreaks of Echo 30 $[14,15]$. Classic virology methods, using cell culture, are routinely used to detect $\mathrm{EV}$ in clinical specimens. In the specific case of AM, the sample of choice is cerebrospinal fluid (CSF). However, since this methodology is time consuming, molecular procedures such as reverse transcription polymerase chain reaction (RT-PCR) have been used [16-19]. We used RT-PCR to look for Echo 30 isolates in cases of meningitis occurring in Belem, in northern Brazil, from March 2002 to December 2003.

Received on 19 March 2007; revised 18 July 2007.

Address for correspondence: Dr. Maria de Lourdes C. Gomes. Instituto Evandro Chagas, Rodovia BR $316 \mathrm{~km} 7 \mathrm{~s} / \mathrm{n}$, Zip code: 67030-000, Ananindeua, Pará, Brasil. E-mail: contentegomes@yahoo.com.br.

The Brazilian Journal of Infectious Diseases 2007;11(4):403-406. (C) 2007 by The Brazilian Journal of Infectious Diseases and Contexto Publishing. All rights reserved.

\section{Materials and Methods \\ $\underline{\text { Patients }}$}

Two-hundred-and-seventy-nine patients, of both sexes; aged from 1 month to 75 years with symptoms of aseptic meningitis were identified from March 2002 to December 2003 in the Pedreira district Health Basic Unit, which belongs to the Public Health Secretary of the State of Para and is located in the city of Belém. An informed consent form was obtained from patients or parents/legal guardians. All patients lived in Belém. CSF samples were obtained from the patients and were divided into two aliquots: one for bacterial and mycological examinations made in the laboratory of the Basic Unit, and an aliquot was conserved in liquid nitrogen for further virus research. Weekly, the samples were carried out to Instituto Evandro Chagas (IEC) in Ananindeua, Pará, being conserved at $-70^{\circ} \mathrm{C}$ until its use.

\section{Laboratory Procedures}

Viral Isolation and Identification

RD and HEp-2 cells (both of human origin) were used in this study. The growing medium (Eagle's Minimum Essential Medium) was harvested and the monolayer was washed with 2 $\mathrm{mL}$ of Hank's BSS. After this, $200 \mathrm{ml}$ of CSF that was clear and negative for bacteria and fungi was inoculated into two tubes of each type of cell. The tubes were maintained in an incubator at $35^{\circ} \mathrm{C}$ for one hour; maintenance medium was then added and the tubes were kept in the incubator for nine days and observed on alternate days. We did a blind passage in the RD-cell cultures. The positive samples were identified with a neutralization test, using hyperimmune specific antisera from NIAID (USA).

\section{RNA Extraction and RT-PCR}

The EV-positive culture fluids were extracted with Trizol reagent and chloroform to obtain RNA. Isopropanol was used 
to precipitate of the RNA and ethanol was used to wash the sediment, which was hydrated with $10 \mu \mathrm{L}$ of water [20]. Part this volume, $3 \mu \mathrm{L}$, was removed and completed to $10 \mu \mathrm{L}$ with primers ( $30 \mathrm{pmol}$ of each) and water $(4 \mu \mathrm{L})$. This mixture was denatured at $95^{\circ} \mathrm{C}$ for 5 minutes. Subsequently, this was added to $40 \mu \mathrm{L}$ of a second mixture: $100 \mu \mathrm{M}$ concentration of each deoxynucleoside triphosphate, $2 \mathrm{mM} \mathrm{MgCl}_{2}, 67 \mathrm{mM}$ Tris- $\mathrm{HCl}$ ( $\mathrm{pH} 8.8), 17 \mathrm{mM}\left(\mathrm{NH}_{4}\right)_{2} \mathrm{SO}_{4}, 1 \mathrm{mM} \beta$-mercaptoethanol, $0.2 \mathrm{mg}$ of gelatin per $\mathrm{mL}, 10 \mathrm{U}$ of placental Rnase inhibitor (Gibco BRL), 7.5 U of Super Script reverse transcriptase (Gibco-BRL) and $5 \mathrm{U}$ of Taq polymerase (Gibco-BRL), following incubation for $30 \mathrm{~min}$, at $42^{\circ} \mathrm{C}$ for cDNA synthesis and for $3 \mathrm{~min}$. at $94^{\circ} \mathrm{C}$ for RT inactivation. This mixture was submitted to 35 cycles of denaturation $\left(94^{\circ} \mathrm{C} 30 \mathrm{sec}\right)$ annealing $\left(42^{\circ} \mathrm{C} 30 \mathrm{sec}\right)$ and extension $\left(68^{\circ} \mathrm{C} 2 \mathrm{~min}\right.$.). The products were submitted to electrophoresis in a $1 \%$ agarose gel, stained with ethidium bromide and visualized under UV-light. The primers were synthesized according to the sequences of the VP4/VP2 (position 0449-0470 and 1211-1192) and VP1/2A (position 26262645 and 3120-3100) region of the genome of the Bastiannistrain prototype of Echo 30 [21].

\section{Results}

Among the 279 CSF samples, 30 (10.7\%) were positive for EV. Among these, 29 were Echo 30 and one Cox B. Of the 29 samples of Echo 30, 19 were checked with RT-PCR; 18 were positive. Twenty nine of the 30 samples were positive in both HEp-2 and RD cells. Each pair of oligonucleotides yielded amplicons with 762 and 494 base pairs. Primer pair VP4/ VP2 showed two bands and pair VP1/2A gave one band (Figure 1). All products with 494 bp were sequenced and confirmed as Echo 30 when compared with Echo 30 sequences deposited in Gen Bank (data not shown). The data concerning age and sex of the patients are shown in Figure 2. The age of the patients ranged from 1 month to 75 years (median age 15.6 years). Overall, $60.9 \%$ (170/279) of these patients were up to 15 years old. The age- group with the highest number of cases was $6-10$ years $(57 / 279-20.4 \%)$, followed by $1-5$ years $(53 / 279$ - $19 \%)$. There was no significant difference between proportions of each gender (135 females and 144 males), but male patients up to 15 years were significantly more affected than those over 15 years, $70.8 \%$ (102/144) and 29.1\% (42/144), respectively $(\mathrm{p}<0.001)$. Among female patients in the same age group, the rates were about the same $50.3 \%$ (68/135) and 49.6\% (67/135), respectively. Clinical symptoms were as follows: fever, $87.8 \%$ (245/279); headache, $82.8 \%$ (231/279); vomiting $66 \%$ (184/279); and neck stiffness, $44.8 \%$ (125/279) (data not shown). Cases of AM occurred throughout the year, with a peak in May, because of an increase in the number of cases in 2002 (Figure 3).

\section{Discussion}

Outbreaks of AM due to Echo 30 have been reported in the Brazilian states of Paraná, Pernambuco and São Paulo, in the south, northeast and southeast Brazilian regions, respectively $[14,15,22]$. Sporadic cases have also been reported in the states of Paraná, Rio Grande do Sul (south region) and Rio de Janeiro (southeast region) [22]. The first occurrence of AM caused by Echo 30 in the northern region was reported by Ferreira et al. [12] in 2002. This virus had been reported formerly in northern region, but it was associated with acute flaccid paralysis cases [23].

In general, AM affects young people. We observed that $51.6 \%(144 / 279)$ of our patients were up to 15 years old. A rate of $58.7 \%$ was reported by Bedoya et al. [9] in cases of acute meningitis in Rio de Janeiro, southeast Brazil, with patients aged between 1 and 15 years. They also reported that meningitis was uncommon in patients less than one month old and above 17 years old. We also did not find patients below one month; however, we identified several patients above 17 years of age. The rate for children up to 5 years old, in our study, was $28.3 \%$ (79/279). A higher rate $(61.3 \%, 398 /$ 648) was reported by dos Santos et al. [22] for children up to six-years-old living in other Brazilian regions. It therefore seems that meningitis cases in children up to five years is less common in children living in Belém than in those who live in other Brazilian regions. We found that the frequency of AM was higher in male patients aged up to 15 years than in males over 15 years old. Khetsuriani et al. [24] also reported that enterovirus in the United States was more frequent among male patients $<20$ years, but not among males $\geq 20$ years.

During the study period (March 2002-December 2003), AM was detected year round, with an increase from March to May and a subsequent decrease thereafter (Figure 3). In 2002 we attributed this a possible seasonal pattern of occurrence; but in 2003 there was no increase of cases in the same period. Twenty-eight positive cases occurred from March to June 2002. The two remaining cases occurred in January 2003. In the Brazilian northern region, there are two well-defined seasons, with heavy rainfall from December to June and a dry season from July to November. The mean temperature in Belém is $26.3^{\circ} \mathrm{C}$, with a no significant variation throughout the year. In our study the peak incidence of AM cases occurred in May, at the end of the heavy rainfall period, when the temperature tends to increase. This finding is similar to that reported by dos Santos et al. [22]. They examined sporadic cases and outbreaks of meningitis in four Brazilian regions during five years; they found a trend for cases to occur mainly during periods of high temperatures.

Using HEp-2 and RD cells, our isolation rate was $10.7 \%$ (30/279). These cells were also used in a study conducted by Silva et al. [11], using CSF obtained from patients with meningitis who live in Salvador, Bahia, in northeast Brazil. In these cases, the isolation rate was $7.5 \%$ (7/94). In another Brazilian study dos Santos et al. [22] reported a rate of $15.8 \%$ $(162 / 1,022)$ using RD and HEp-2 cells. A higher rate $(53 \%, 36 /$ 68) was reported by Guney et al. [18] who studied AM in Turkey. These authors inoculated CSF specimens into HeLa, HEp-2 and RD cells. In another study, conducted by Thoren and Widell [17], the isolation rate in green monkey 
Figure 1. Agarose gel showing five of the 17 Enteroviruspositive samples; molecular weight $123 \mathrm{bp}$.

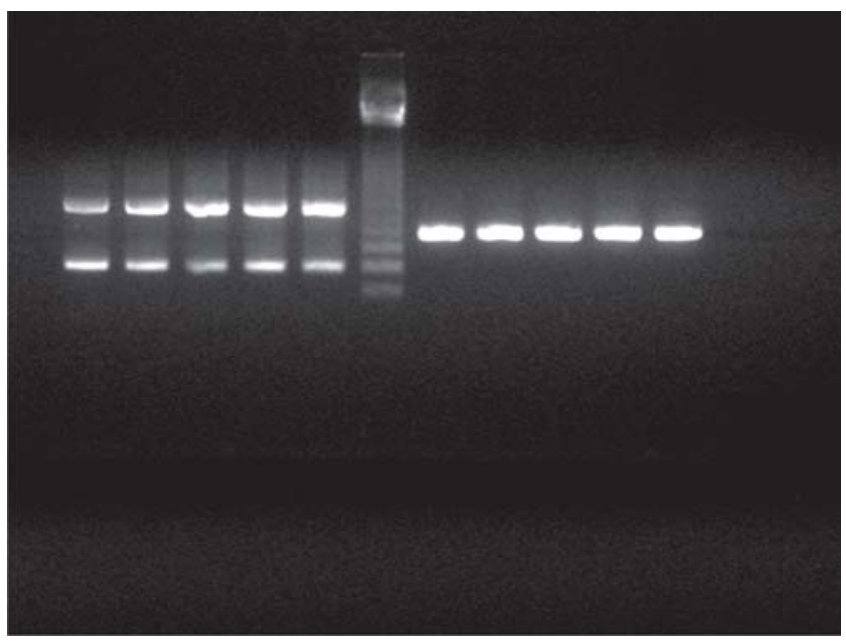

Figure 2. Distribution of 279 patients with suspected aseptic meningitis, according to gender and age, from March 2002 to December 2003, living in Belem, Brazil.

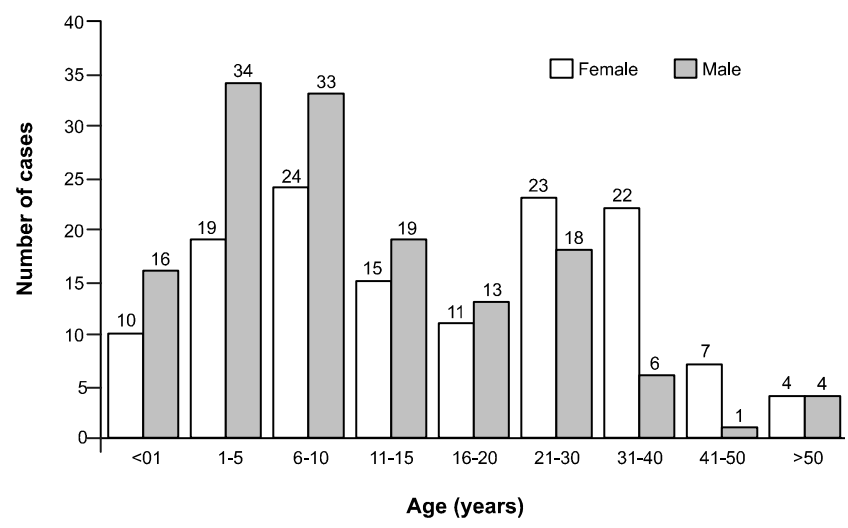

Figure 3. Monthly distribution of the 279 patients suspected of aseptic meningitis, occurring in Belem, from March 2002 to December 2003

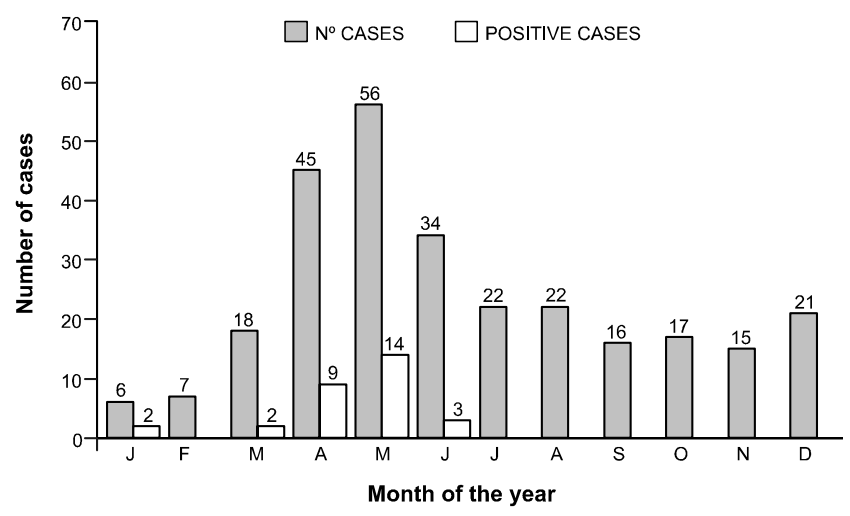

kidney (GMK) cells and human embryonic fibroblasts (HEF) was $22 \%(6 / 27)$. It is likely that the type of cell and their different origins influence in isolation rates. Kupila et al. [19] reported 17 (50\%) EV-positive samples among 34 CSF samples from Tuku, Finland. They did not specify the cells used. We found two different EVs: Echo $30(n=29)$ and $\operatorname{Cox} B(n=1)$. Guney et al. [18], in a study of CSF of children with AM in Turkey, found 35 viral isolates, which were typed as Echo $30(n=30)$ and Cox B $(n=5)$. These viruses were also the most often commonly identified by dos Santos et al. [22] in 169 CSF specimens from meningitis cases that occurred in four Brazilian regions; Echo 30 - 85.2\% (139/162) and Cox B - 3.7\% (5/162).

In classic virology, neutralization tests using specific antisera are commonly used to identify viral isolates. As such procedures are time consuming, other procedures such as RT-PCR, which give results in a short time, are being increasingly used. In our study, RT-PCR permitted us to identify Echo 30 in 18 of 19 EV-positive cell-culture-fluid samples. Savolainen et al. [21], using sequence primers from the VP4/VP2 regions, obtained 131 Echo 30 strains, including the prototype strain Bastianni. When they used primer sequences from the VP2/2A regions, 63 Echo 30 strains, including the prototype strain Bastianni, were obtained. We had similar findings, considering that among the 19 Echo 30 samples, 18 tested positive with primer pairs from these two regions. The negative RT-PCR sample should be used with other pair of primers constructed based on other nucleotide sequences from the genome region.

Since the Brazilian Ministry of Health is currently implementing a national surveillance network for viral meningitis, we recommend that uniform procedures be used throughout country in order to better assess the frequency of this disease in Brazil, so that authorities can develop more effective control measures.

\section{Acknowledgements}

We are grateful to Dr. Alexandre C. Linhares for the revision of this article.

\section{References}

1. Reeves W.C., Quiroz E., Brenes M.M., et al. Aseptic meningitis due to echovirus 4 in Panamá city, Republic of Panamá. American Journal of Epidemiology 1987;125(4):562-75.

2. Rodríguez R.S., Gómez-Barreto D., Pallansch M., et al. Brote epidémico de meningitis viral causado por virus ECHO tipo 30. Bol Med Hosp Infant Mex 1992;49(7):412-5.

3. Cernescu C., Tardei G., Ruta S., et al. An outbreak of aseptic meningitis due to ECHO 30 virus in Romania during the 1999 summer. Rom J Virol 1999;50(1-4):99-106.

4. Schumacher J.D., Chuard C., Renevey F., et al. Outbreak of Echovirus 30 meningitis in Switzerland. Scand J Infect Dis 1999;(31):539-42.

5. Sarmiento L., Mas P., Goyenechea A., et al. First Epidemic of Echovirus 16 Meningitis in Cuba. Emerging Infectious Diseases 2001;7(5):887-9.

6. Kirschke D.L., Jones T.F., Buckingham S.C., et al. Outbreak of aseptic meningitis associated with echovirus 13. Pediatr Infect Dis J 2002;21:1034-8. 
7. Ozkaya E., Hizel K., Uysal G., et al. An outbreak of Aseptic meningitis due to echovirus type 30 in the cities of Turkey. Eur J Epidemiol 2003;18(8):823-6.

8. Godoy C.V.F., Carvalho R.P.S., Kirchner E., et al. Síndrome de meningite asséptica. Esclarecimento etiológico de alguns casos na cidade de São Paulo. Considerações clínico-laboratoriais. Rev. Inst. Med. trop. São Paulo 1967;9(4):213-21.

9. Bedoya S.P., Trocoli M.G.C., Da Silva E.E., Leite J.P.G. Detection of virus by polymerase chain reaction in cases of acute meningitis. Virus Reviews \& Research 1998;3(Supplement 1):98.

10. Gomes M.L.C., Kopecka H., Linhares A.C. Detection of enteroviruses in cases of neurological disorders in the state of Pará, Brazil. Rev Inst Med Trop S Paulo 2001;43(6):321-4.

11. Silva H.R., Tanajura G.M., Tavares-Neto J., et al. Sindrome de meningite asséptica por enterovírus e Leptospira sp. em crianças de Salvador, Bahia. Revista da Sociedade Brasileira de Medicina Tropical 2002;35(2):159-62.

12. Ferreira L.L.A., Lamarão L.M., Santos M.C., et al. Detecting of Enterovirus (EV) in cases of aseptic meningitis (AM) occurred in Belém, Pará, Brazil. Virus Reviews \& Research 2002;7:146.

13. Lamarão L.M., Gomes M.L.C., Ferreira L.L.A., et al. Pesquisa de Enterovírus em Casos de Síndrome de Meningite Asséptica de Belém. Revista da Sociedade Brasileira de Medicina Tropical 2005;38(5):391-5.

14. Jóia A.E.B., Figueiredo M.H., Skaba I., et al. A large outbreak of aseptic meningitis caused by echovirus 30 in Paraná, Brazil. Virus Reviews \& Research 1999;4(Supplement 1):141.

15. Timenetsky M.C.S.T., Carmona R.C.C., Machado B.C., et al. Aseptic meningitis by echovirus 30 in São Paulo State. Virus Reviews \& Research 1999;4(Supplement 1):118.
16. Glimaker M., Johansson B., Qlcén P., et al. Detection of Enteroviral RNA by Polymerase Chain Reaction in Cerebrospinal Fluid from Patients with Aseptic Meningitis. Scand J Infect Dis 1993;25:547-57.

17. Thorén A., Widell A. PCR for the Diagnosis of Enteroviral Meningitis. Scand J Infect Dis 1994;26:249-54.

18. Guney C., Ozkaya E., Yapar M., et al. Laboratory diagnosis of enteroviral infections of the central nervous system by using a nested RT-polymerase chain reaction (PCR) assay. Diagnostic Microbiology and Infectious Disease 2003;47:557-62.

19. Kupila L., Vuorinen T., Vainionpââ R., et al. Diagnosis of Enteroviral Meningitis by Use of Polymerase Chain Reaction of Cerebrospinal Fluid, Stool, and Serum Specimens. Clinical Infectious Diseases 2005;40:982-7.

20. Chomezynski P., Sacchi N. Single-step method of RNA isolation by acid guanidinium thiocyanate-phenol-chloroform extraction. Anal Biochem 1987;162:156-9.

21. Savolainen T., Hovi T., Mulders M.N. Molecular epidemiology of echovirus 30 in Europe: succession of dominant sublineages within a single major genotype. Archives of Virology 2001;146:521-37.

22. Dos Santos G.P.L., Skraba I., Oliveira D., et al. Enterovirus Meningitis in Brazil, 1998-2003. Journal of Medical Virology 2006; 78:98-104.

23. Gomes M.L.C., Nakauth C.M., Freitas R.B., Macedo O. Poliomielite e outras enteroviroses. In: Instituto Evandro Chagas; 50 anos de contribuição às ciências biológicas e à medicina tropical. Belém, Fundação Serviços de Saúde Pública 1986;591-600.

24. Khetsuriani N., LaMonte-Fowlkes A., Oberste S., Pallansch M.A. Enterovirus Surveillance United States, 1970-2005. MMWR 2006; 55(SS08): 1-50. 